\title{
The Adaptation of English Consonants by Efik Learners of English
}

\author{
Eyo Mensah ${ }^{1} \&$ Eyamba Mensah ${ }^{1}$ \\ ${ }^{1}$ Department of Linguistics and Communication Studies, University of Calabar, Nigeria \\ Correspondence: Eyo Mensah, Department of Linguistics and Communication Studies, University of Calabar, \\ Nigeria. E-mail: eyomensah2004@yahoo.com
}

Received: November 28, 2013 Accepted: December 29, 2013 Online Published: February 12, 2014

doi:10.5539/elt.v7n3p38 URL: http://dx.doi.org/10.5539/elt.v7n3p38

\begin{abstract}
One of the linguistic outcomes of the sustained contact of a target language (L2) with a source language (L1) in the course of history is the adaptation and integration of loanwords from the former into the lexicon of the latter. This paper discusses the phonological strategies and parameters for the adaptation of English consonants (which mainly affect nouns) into Efik. The paper discusses the factors that are responsible for borrowing and convergence as well as the linguistic consequences of loanwords in the Efik expanded vocabulary. We submit that though the pattern of borrowing is tailored to agree with the phonological system of the source language, some of the changes are however, as a result of indigenous innovations or prosodic patterns. We argue in this paper that target-source language contact phenomenon is an important source of lexical enrichment of the target language, which has expanded its functional domains to cope with modern challenges. The paper considers the implication of the study for the English language teaching and learning classroom in the Efik non-native environment.
\end{abstract}

Keywords: loanwords, language contact, consonants, lexical enrichment, Efik, language teaching, learning, bilingualism

\section{Introduction}

Efik is the language of the Efik people who occupy the coastal areas of the Cross River Basin comprising Akpabuyo, Bakassi, Calabar Municipality, Calabar South, and Odukpani Local Government Areas of Cross River State, Nigeria. Given the long-standing widespread of Efik as the local lingua-franca along the entire South-eastern coast of Nigeria (including the present-day Akwa Ibom), it traces can still be found in places like Uruan, Itu, Oron, Akamkpa, Ugep, Ikom and Obubra among others. The Efik language has been classified as a member of the Lower-Cross family of languages within the Delta-Cross family of the enlarged Benue-Congo group of languages (Greenberg, 1963; Faraclas, 1989). The Efik language had served as a local lingua franca for over a century along the entire Cross River basin, comprising the Southeastern region of Nigeria up to Ogoja and Bekwarra in Upper-Cross River region. The language is spoken by about 3 million second speakers and 1.5 million native speakers (based on 2007 census demographic data). Faraclas (1989, p. 394) describes the Efik language as "one of the best studied languages in Africa" The language is currently enjoying robust linguistic scholarship as it is studied up to the degree level in the area it is spoken predominantly. Scholarly attention was initiated in the language as far back as 1864 when a complete Bible was translated into the language (Cook, 1969, 1986). During this period also, a dictionary was compiled and some linguistic descriptions of the language were undertaken by missionaries, Europeans business men, and later colonial administrators. Every aspect of the language has been widely studied particularly at the Universities of Calabar and Uyo, and a few Colleges of Education around the former South-eastern region. Efik is also widely used in the mass media and religious worship. It is one of the languages in Nigeria with a well planned status and corpus.

The Efik people were some of the earliest indigenous African people along the coast of West Africa to establish contact with the Europeans. Nair (1972) records that the Portuguese and British were the first sets of people to arrive the shores of Efikland. This early contact ignited potential interest in trade, especially in slaves and later in oil palm. The interest later shifted to missionary endeavors, particularly with the arrival of the Scottish Presbyterian Mission (Now Presbyterian Church) in 1862, and later the Catholic mission in the early 18th century in addition to others nativised missions. It is interesting to note that early linguistic works on Efik were carried out by the missionaries. Hugh Goldie, a Presbyterian clergy in Creek Town, Western Calabar devised the first orthography of Efik and also compiled a bilingual dictionary (Efik-English), the first lexicographic project 
in any indigenous pre-colonial Nigerian language. The Efik people were also taught how to read and write their language by the missionaries (Nair, 1972), given the combined benefits of training translators in the language to facilitate the growth of the missionary endeavours and the need to promote literacy, so that the people could readily appreciate the socio-moral lessons contained in the Bible.

Given the preponderance of missionaries' activities in addition to trade concerns and colonization of Efikland by the Europeans, it became near-natural process for the speakers of Efik to come into contact with the English language and its culture. As a result of this convergence, a number of words in the Efik lexicon were borrowed from English through a variety of morphological processes such as calquing, translation and transliteration, and the sounds have been assimilated and simplified to agree with the phonological inventory of Efik before they are adapted and integrated into the lexicon. We agree with Thomason and Kaufman (1988) that in cases of intensive contact between speakers of different languages, it is the language of the group that has more socioeconomic or political power that becomes the source of borrowing, and that the more intense a contact is, the more opportunity there is for bilingualism to develop and consequently the more borrowing takes place. It is important to note that loanwords (in our context, words which are borrowed from English into Efik) are adapted to suit the morphological and phonological systems of the recipient language, which is our case, is Efik. This position is in agreement with Kenstowicz and Suchato (2006) who argue that loanword adaptation implies that speakers will show faithfulness to the source words and at the same time try to make loanwords conform to their native segmental inventory, phonotactic constraints and morphological systems.

A sound is the natural medium for the transmission and reception of language and speech sounds are distinctive sets of sounds in a given language. Two classes of sounds, vowels and consonants, are usually classified as speech sounds. According to McMahon (2002, p. 68), both classes of sounds play complementary roles in structuring syllables and words, and both are formed by modifications of moving airstream, carried out by the action of the vocal folds and the articulatory organs. Vowels are produced with no audible friction in the vocal tract while there is turbulent flow of air in the vocal tract during the production of consonants. These two classes of sounds combine to form higher units of language. It has been noted in the literature (Cook, 1969; Mensah \& Ojukwu, 2003) that consonants pose greater learning difficulty to the Efik learners of English than vowels. This is due to the greater discrepancy in the consonant inventories of the two languages. The tendency is for the Efik learner to transfer L1 sounds to L2 performance, which usually results to interference. Interference may also affect other extra-linguistic features of speech such as intonation, stress, rhyme, and intonation. However, this paper sets out to investigate the strategies of adapting English consonants by the Efik learners of English with a view to making some predictions on how such consonant sounds can be effectively handled in the English language classroom in an attempt to help learners achieve intelligible pronunciation. Intelligibility in this context implies the extent to which a speaker's message is actually understood by a listener (Munro \& Derwing, 1995; Nelson, 1995) in the teaching and learning of the Standard English language in non-native contexts. As a build up to our discussion, we also examine the mechanism of lexical borrowing in Efik and consider a comparative survey of basic Efik and English phonological systems. In what follows, we examine the theoretical framework that informed our analysis and interpretation of data.

\section{Theoretical Prerequisite}

This study is rooted in the contrastive analysis procedure in language-teaching pedagogy which systematically compares two or more languages structures or subsystems in order to identify the similarities and differences between them "so that the more effective language-learning materials based precisely on these language problems can be developed" (Hadlich, 1965, p. 426). Contrastive analysis aims at establishing explicit similarities and differences between two or more languages or cultures in terms of correspondence and equivalence between elements in those languages and cultures. Fisiak (1981, p. 2) argues that the main focus of contrastive studies is the problem of how a universal category $\mathrm{X}$, realized in language A as $\mathrm{Y}$, is rendered in language $\mathrm{B}$ as $\mathrm{Z}$, and what may be the possible consequences of this for a field application.

Theoretically, contrastive analysis has applied and pedagogical significance given its investigative approach in bringing about distinctions and similarities in languages. Lado (1957) maintains that through contrastive analysis, we can predict and describe the patterns that will cause difficulties in learning and those that will not by systematically comparing the structures of L1 and L2, and observed changes can be equated to the differences in L1 and L2 and their respective cultures. The differential aspect of the structure of the two languages can be highlighted through this parallel description which involves different structural levels such as sounds, word structure or order, syntax and meaning. Transfer of meanings, sound or other features from L1 to L2 occurs productively when a learner attempts to grasp L2 meanings and its culture. This is usually used as a parameter to predict learner's error, basically due to mother tongue interference in their performance in the target language. 
This phenomenon is known as negative transfer as opposed to positive transfer which affects the features or elements in L1 and L2 that are similar and consequently facilitate the understanding of L2.

In examining the adaptation of consonants in English loanwords by Efik learners of English, contrastive analysis procedure has provided insights that have enabled us distinguish the phonemes in the source and target languages, compare their syllabic system (consonant cluster-permitting and non-cluster permitting), as well as the effect of the presence or absence of non-segmental features like stress, tones and intonation in the languages compared. The aim is to enable us design an efficient teaching and learning methodology and deemphasize greater attention to text but on structure in the teaching of grammar. It has been noted in the literature (Wardhaugh, 1970; Rustipa, 2011) that contrastive analysis as a component of contrastive linguistics is fast becoming less attractive or fashionable as an approach in contemporary foreign language pedagogy by experts, applied linguists, translators and foreign languages' educators due to its overwhelming dependence on predicting only one type of error, interference.

\section{Motivations for Lexical Borrowing}

A number of factors have been responsible for the borrowing of English words into the Efik lexicon. In Southern Cross River State where Efik is the language of the majority indigenous people, English is an indispensable factor in the market economy and the mainstream society. It is the official language within government circle and a compulsory school subject at every level of education. It is the language of the media, both print and electronic, in addition to the enormous sociopolitical roles it plays in the city. Colonization also contributed immensely in the imposition of English on the Efik people. The use of English in education and administration became a yardstick for inclusion and exclusion. The colonial administrators did not only adopt the all English policy unlike the missionaries but embarked on a mission of renaming popular Efik streets in English. Today, such street names like Wilkie, Egerton, Macdonald, Fosbery, Anderson, John Stone, Beecroft, McGregor, Ballyantine and Watt are common place names in Calabar, the Efik capital.

Some of the mission churches rejected Efik names in baptism and compelled converts to adopt English, Biblical or baptismal names, thus condemning the people's indigenous names as "fetish". Some of the indigenous names actually have metaphysical presuppositions and ritual connections that were against Christian teachings and beliefs. The new Pentecostal movement represents a flagship for foisting this kind of rejection of indigenous names and culture. The above painted scenario reveals that Efik had long been neglected at the expense of English and that the two languages have existed in a sustained diglossic context. There is also the question of prestige which is attached to one's performance in English. Most parents outlaw the speaking of Efik at home among their children believing that it could interfere with their proficiency in written and spoken English. The result is that most educated speakers of Efik are bilinguals. To the average Efik person, one's yardstick of being educated is his ability to speak the English language fluently. So no proper education can be complete without English. The production of bilinguals is predicated on the exhibition of other linguistic behaviour like language mixing, borrowing and convergence. These are verbal behaviour that are common place and accepted by the Efik speech community as normal. Given the contact between Efik and English, a number of English loanwords have been adapted and integrated into the Efik lexicon in a bid to cope with modern challenges by expanding the vocabulary to cover a wide range of functional domains. The modernization of Efik has been focused on the creation of lexical items to describe technical concepts and terms geared towards status planning for the language.

A cursory examination of English loanwords in the Efik lexicon reveals that there are different categories of borrowing which took place at different phases of history. For the purpose of our study, we categorize them into traditional and contemporary loanwords. The traditional period encompasses borrowed forms that represented cultural vocabulary and foreign concepts which were alien to the Efik culture while the contemporary are mainly lexical items which reflect modern challenges of reality and which lack equivalence in the Efik language and culture. Some of the words that were borrowed historically into Efik vocabulary include tíandé "candle", tián "zinc", bábru "paper", siọd "shirt", édésì "rice" súkà " sugar", sika "cigarette" and ákrásì "glass" etc. These were mainly British cultural items which were newly introduced to the Efik people. The meaning of these items was culture-specific of which the Efik people have to learn through the experience of their own culture. This state of affairs affirms Hoffman (1991) claim that the English language is the most prolific donor giving words to most languages in Europe and beyond. Since there were no appropriate words within the Efik linguistic resources to represent these English cultural referents, the words were borrowed, simplified and assimilated in the direction of the Efik phonology.

Another form of borrowing is the development of loan shift, that is, creation of words made up entirely from 
native sources. It involves the calquing of English lexical items to create meaning that was representative in Efik. Such lexical items include ékébé útiñ iko (box + speaking) "radio", ékébé ndisè (box + picture) "television", ékébé ntùkùbè (box + cold) "refrigerator", mbùk nkpo ntìbè (story + happenings) "news", àbàsì itá ké kièt (God + threesome) "trinity". These lexical items were created by analogous extension. According to Spencer (1991), these words are lexicalized to somewhat different constructions to convey the people's impressions about objects, ideas and concepts which were alien to their culture. Another method of borrowing was the habitual association of the word mmákárá "Whiteman" with some cultural vocabulary in Efik in other to distinguish such words from the existing forms. For instance, we have únèn "fowl" únèn mmákárá "duck", isíp "kernel" isíp mmákárá "coconut", ábiaibọk "herbaist", ábiaibọk mmákárá "medical doctor", iko "word" iko mmákárá "English language" etc. The perception of the people was that since it was the Whiteman that introduced the new items, they should be collocated with the form (representing him) to bring about the referential meaning of the words. Although these collocations are based on natural roots, they are manifestly borrowed.

Cultural vocabulary in English are borrowed into Efik through metaphorical extension, which is a type of semantic widening, where in, on the basis of some similarity in meaning, a word is used in different sort of context, and reference to different sorts of features (Robin, 1989, p. 345). In other words, the correspondence of meaning of two or more words is used and understood in a related and recognized way. Instances of metaphorical extension include words like úbóm ófùm (canoe + air) "airplane", nsùn íkañ (smoke + fire) "ship", úfọk-ényoñ (house + sky) "storey building". There is no direct semantic link that holds between the compounding forms that have produced the resultant words. The individual meaning of the compound words does not sum up the overall meaning of the words, though they share some features or elements of meaning.

Also of note is ideophonic borrowing where the meaning of English objects are derived directly from the sounds usually associated with such objects. Such borrowing include ekikọ "cock", nái nái "tray, nsák "rattle", òbùkpòn "trumpet, ikpáñ "spoon”, ákpáñ-akpáñ "brass tray” etc. The meanings of these words are understood as a result of sound correspondence with the objects they represent. One can say that while traditional borrowing reinforces cultural contact between Efik and English, contemporary borrowing depicts technological contact between them. These are mainly new vocabulary items that reflect modern realities and contemporary challenges of the expanding world. These lexical items cover wide-range areas of human endeavors and capabilities. They represent technical vocabulary in medicine, engineering, arts and the emerging technologies in information, communication and education. Most of the data for this study were drawn from this modern era of borrowing which have been adapted and conventionalized into the Efik lexicon and which to a greater extent are representative of English pronunciation and graphemes.

Some language purists have risen against borrowing as a form of linguistic sabotage, impurity, or pidginization of a natural language (Ahukanna, 1990). Mensah (2010) however, argues that borrowing is a natural means of enhancing the internal resourcefulness of a language like Efik. Many English adapted words have gained currency into the lexicon of Efik, and there has been orthographic alteration of the spelling system to align with Efik phonology. To a large extent, borrowing is a form of expansionism and revivalism movement of African languages.

\section{Basic Efik Phonology}

In an attempt to facilitate our analysis of loanwords adaptation in Efik, we present the Efik and English phonological systems in Table 1 and 2 respectively and a description of their basic phonology.

Table 1. Efik phonetic consonants

\begin{tabular}{|c|c|c|c|c|c|c|}
\hline Place/manner & Labial & Alveolar & Palatal & Velar & Labialized velar & Glottal \\
\hline Plosive & $\mathrm{b}$ & $\mathrm{d}$ & & $\mathrm{k}$ & $\mathrm{kp}$ & \\
\hline Fricative & $\mathrm{f}$ & $\mathrm{s}$ & & & & $\mathrm{h}$ \\
\hline Nasal & $\mathrm{m}$ & $\mathrm{n}$ & $\mathrm{n}$ & $\mathrm{y}$ & nw & \\
\hline Trill & & $\mathrm{r}$ & & & & \\
\hline Approximant & & 1 & $\mathrm{j}$ & & $\mathrm{w}$ & \\
\hline
\end{tabular}

Table 1 reveals that Efik has 17 phonetic consonant sounds and 15 phonemes. The phonemic status of $/ \mathrm{p} /$ and $/ \mathrm{r} /$ is suspect since they cannot pass the minimal pair test. $/ \mathrm{p} /$ is usually analysed as an allophone of $/ \mathrm{b} / \mathrm{while} / \mathrm{r} /$ is sometimes described as an allophone of $/ \mathrm{d} /$. A few consonant sounds $/ \mathrm{b}, \mathrm{t}, \mathrm{d}, \mathrm{k}, \mathrm{m}, \mathrm{n}, \mathrm{y} / \mathrm{can}$ occur in all environments. A few others occur only in initial and medial positions $/ \mathrm{f}, \mathrm{s}, \mathrm{j}, \mathrm{w}, \mathrm{kp}, \mathrm{n} /$. The glottal fricative $/ \mathrm{h} /$ is 
found in only medial positions in conformity with the phonotactic rules of Efik. Rowan (2013) maintains that in word initial position, Efik consonants are strongly articulated whereas other positions evidence consonantal weakening effects such as $\mathrm{k} \rightarrow[\mathrm{h}] /[\mathrm{x}], \mathrm{d}, \mathrm{t} \rightarrow[\mathrm{r}]$ and in word final position, $/ \mathrm{b} /$ and $/ \mathrm{d} /$ are realised as unrealised voiceless stops $/ \mathrm{p} /$ and $/ \mathrm{t} /$ respectively. The sounds $/ \mathrm{p} /$ and $/ \mathrm{kp} /$ occur in complementary distribution while the bilabial stop occurs only in word final position, the velar stop occurs initially and medially.

Efik utilizes two types of tones, register and contour tones in its tonemic system. The register tones (high and low) and the contour tones (rising and falling) are used to distinguish meaning of lexical items, ékpád "log (of wood)" vs èkpàd "bag", ánwá "outside/frontage" vs anwâ "cat". The downstep tone can only manifest in high tones, e.g $o b o ! n$ "king". Tones may also be used to express grammatical relations involving categories such as tense, aspect, question etc. Ádiá ñkpo "Are you eating?" vs Ádía ñkpo "S/he is eating". Here, tone is used to differentiate a question from a progressive aspectual event. The predominant syllabic structure involving monosyllabic verbs are CV (bê "pass", tá "chew" dé "sleep) and CVC (bét "wait", tát "unloose", dép "buy"). Majority of Efik nouns begin with vowels, hence have the primary syllabic structure VCV (ébé "husband, ùkè "mate") or VCVC (ùsàn "plate", ókúk "money"). A few nouns together with other word classes begin with consonants or syllabic nasals and fall into the primary syllabic template of Efik.

Efik has 5 phonemic vowels (a, e, i, o, o, u) and 8 phonetic vowels $(\varepsilon, i ̣, u)$ which mainly exist in harmonic relationship with one another. Ward (1933, p. 19) identified six vowels phoneme in Efik. She however argues that in the Goldie's alphabet, It was seen that two $e$ symbols were formerly used; viz. $e$ and $\ddot{e}$, the first representing a closer and the second a more open vowel. In later Efik writing, she maintains that the symbol $\ddot{e}$ was discarded, and this point to the fact that little difference was felt to exist between the two vowels. From her own analysis, she came to the conclusion that there are two varieties of $e$, a closed and a more open one. However, it has not been possible to formulate rules governing the use of these two varieties of $e$, because according to her, "it does not seem necessary, therefore to mark the difference".

In the present study, we agreed that two allophones of $/ e /$ exist in Efik viz. /e/ and $/ \varepsilon /$, and formulate that while the former retains its full value in all positions in Efik, the latter is only found in word initial position usually functioning as a concord marker representing the third person singular. The contrast between $/ \mathrm{i}, \mathrm{u} /$ and $/ \mathrm{i}, \mathrm{u} /$ is basically that of length. The latter are generally short vowels.

\section{Basic English Phonology}

Table 2. English phonetic consonants (source DJPD 16, 2003).

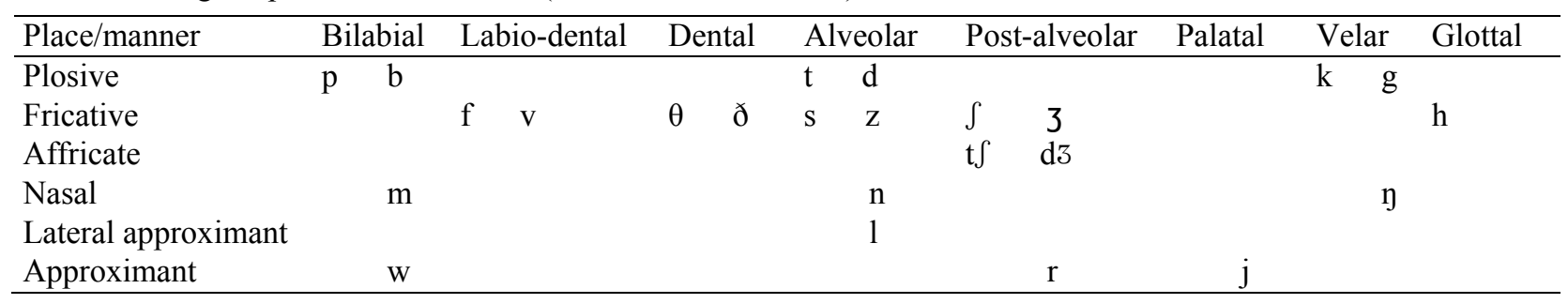

The British English, otherwise known as the Received Pronunciation (RP) (which is the reference point for the present study) has 24 consonant phonemes which may appear singly or in clusters. Some of the sounds are realised as different allophones. The nasal consonants are syllabic. Approximant sounds like $/ \mathrm{j} / \mathrm{and} / \mathrm{w} /$ are usually analysed as semivowels. /j/ exhibits vowel-like characteristics usually at the beginning of a word or in the syllable before a vowel, e.g (yellow, fairy). The sound $/ \mathrm{w} /$ also represents the vowel sound $/ \mathrm{u}$ :/ in most diphthongs (owl, brown, low). This is what Anderson (2001) calls deconsonantalization of $/ \mathrm{w} / \mathrm{and} / \mathrm{j} /$ in which case, the sounds are no longer contrastively consonantal but sequential variants of their full vowel congeners. The phonotactic rules also constrain some sounds in some environment of occurrence, e.g, the velar nasal $/ \mathrm{y} /$ does not occur word initially, the post-alveolar fricative $/ 3 /$ and affricate $/ \mathrm{d} 3 /$ do not occur in word-final positions in English, though the latter may also occur word-initially.

In English, a single vowel (V) may constitute a syllable [ai] 'eye', a vowel preceded by or followed by a consonant CV [pai] "pie", VC [it] "it". English syllables also have varies structures of a vowel preceded by or followed a cluster of consonants; CCV [trai] "tray", CCCV [sprai] "spray", CVCCC [tekst] "text", VCC [its] "its" and CVCCCC [teksts] "texts". Borowsky (1989) however argues that the possible sequence of consonants found in word-initial positions are not an altogether true reflection of the possible sequence found in syllable-initial and 
syllable-final positions given that English often allows violations of syllable structure at word edge in compliance with the principle of structure preservation. In a sequence of two or more syllables, some syllables appear longer and louder than others, hence become stressed. English has particular patterns of stress that affect sentences, phrases, words and affixes. Delahunty and Garvey (2003) maintain that word stress in English is not generally predictable as only partial generalizations are possible. This means that learners have to learn these partial generalizations and where they apply as well as stress placement in words in which stress is not possible. Some of these generalizations include the fact that content words are stressed more than function words and that nouns, adjectives and adverbs are stressed more on the first syllable, verbs with prefixes on the second syllable and prefixes are often stressed in nouns and less often in verbs. At the level of sentence, stress creates a change in focus and causes the sentence to take a new meaning. Another important non-segmental feature of English phonology is intonation which has properties with contrastive or non-emphatic tonic stress to give new information or convey a variety of feeling or attitude. Celtik (2001) points out that these continuous streams of sounds bounded by fairly perceptible pauses facilitate information packaging as well as the desire to understand or be well understood.

The standard British English or RP has eight cardinal vowels with four main reference points which map out the auditory abstract vowel space. The sounds define the appropriate reference points representing the limit of possible vowel quality; height, narrowing, back and low. They also allow the parameters for the classification of vowels to be defined; front vs back, high vs low, and lip rounding. The phonological system of Efik is contrasted with that of English to see the extent to which the structures of the two languages differ. The implication is that English and Efik do not have the same inventory of sounds and there are observed asymmetrical patterns of non-segmental features in the two languages. English borrowed words have to be adapted phonologically to conform to the inventory of Efik. This however, has turned out to be a source of error which causes learners to deviate from achieving intelligible pronunciation in an attempt to be communicatively efficient in their performance in English. In the following discussion, we examine the methods of data collection.

\section{Methodology}

Forty Efik-English bilinguals constituted the population of this exploratory qualitative study. The sampled population was made up of 20 males and 20 females aged between 15-30. The respondents were from within the University campuses (University of Calabar and Cross River University of Technology, Calabar, Nigeria) and two secondary schools in Calabar metropolis. The undergraduates were mainly students in language-related fields - linguistics, modern languages, Translation, English and Literary Studies. Random sampling technique was employed in the choice of the respondents. Since the study was carried out in an area where Efik is predominantly spoken (the language of the immediate environment), it was not really tasking selecting the respondents randomly. They study English as a compulsory subject of the curriculum in Secondary School or 14 years at the University level and we aimed to find out if different levels of proficiency in English would make a difference in the perception and adaptation of loanwords. The ratio between the college participants and the undergraduate participants was 50-50. The participants were brought together and given a corpus of 100 English loanwords representing the various consonant sounds in English and were required to reproduce the equivalent of each word in Efik. Another method of data collection was the use of oral or personal interviews, which were scheduled at a different day with a cross section of the respondents. A tape recorder was used in recording sampled data through participant observation. A corpus of rich loanwords and their adaptation was also recorded in natural conversation among respondents who are Efik learners of English. Data which form clear distinction between language switching and borrowing by respondents was also elicited. All recordings were transcribed and glossed to capture the adaptation of consonants. We were able to subject the data to linguistic analyses.

\subsection{Procedure}

Based on these data elicitation approaches, we made auditory similarity judgment on the basis of an input form. We evaluated the effect of perceptual similarity between a target sound and actual realization in the source language. We also evaluated the effect of perceptual differences between a target sound and actual realization in the source language. We noted the breaking of different categories of consonant clustering in actual realization in the source language. In examining the sounds, we also paid attention to issues of graphemes given that there is no direct correspondence between sound and symbols in the target language while in the source language, the relationship between spelling and pronunciation is a bit more predictable. Based on our adopted conceptual framework, we are able to point out conspicuous differences in the adaptation of loanword consonants and predict areas of difficulty that errors will take place. This will not only help us to explain such errors but also help to fill interlingual and phonological gaps in the learning of English by Efik bilinguals. 


\subsection{Analysis of Data}

In contrasting the consonant sounds of Efik with English, it is evident that the following English sounds are not attestable in the Efik inventory $\left[\mathrm{v}, \theta, \mathrm{\partial}, \mathrm{z}, \int, 3, \mathrm{t} \int, \mathrm{d} 3\right]$ while it is only the palatal nasal sound [n] that is in the Efik inventory but absent in English. This evidence goes to show that adaptation of consonant sound in Efik becomes inevitable. In the analysis that follows, we examine the adaptation of the following categories of consonants; labial, dental, alveolar, palatal, velar and glottal. Our analysis is base on the phonological approximation view of loanword adaptation, which contends that L2-L1 mapping occurs on the basis of phonological distance rather than phonetic distance between categories; a L2 segment is replaced by L1 segment that is the closest phonologically (in terms of features) and not necessarily the segment that is closest perceptually (Paradis \& Lacharite, 1997, 2008; Chang, 2008).

\subsubsection{The Adaptation of Labial Consonants}

From Tables 1 and 2, Efik has the following labial consonants /p, b, f, s, m/ and English has the following /p, b, f, $\mathrm{v}, \mathrm{s}, \mathrm{m}, \mathrm{w} /$. There is a clear absence of the voice labio-dental fricative $/ \mathrm{v} /$ in the Efik inventory in addition to phonotactic issues involving other sounds in this category. We begin the analysis with the bilabial stops, which though are present in the two languages are perceptually different in their behaviour in certain environments:

(1) $\mathrm{RP}$

$\begin{array}{lll}\text { /pəli:s/ } & \text { [bórísì] } & \text { - police } \\ \text { /pə:pə/ } & {[\text { bib1 }]} & \text { - pawpaw } \\ \text { /ka:pəntə/ } & {[\text { kábíntà] }} & \text { - carpenter } \\ \text { /kætəpila/ } & \text { [kátákpílà] } & \text { - caterpillar }\end{array}$

Insights from the theory of contrastive analysis, where the presence or absence of a sound in the recipient or target language can bring about positive or negative transfer can be used to explain the general pattern of loanwords adaptation in Efik. As we stated earlier, the voiceless bilabial plosive /p/ is an allophone of its voiced counterpart $/ \mathrm{b} /$ and is phonologically constrained to only the word final position in Efik. It is realized as $/ \mathrm{b} /$ in initial position. In the medial position, it is realised either as its voiced counterpart or as labialized velar $/ \mathrm{kp} /$. The adaptation of $/ \mathrm{p} / \mathrm{as} / \mathrm{b} /$ indicates that voicing is one of the phonological nativation processes to maintain permissible phonological structure in the L1 system. The change from $/ \mathrm{p} /$ to $/ \mathrm{kp} /$ is a consonant substitution process in terms of phonological closeness. The absence of the voiced labio-dental fricative $/ \mathrm{v} /$ makes it possible for its adaptation as its voiceless counterpart / $f /$ in both the initial and medial positions by the Efik learners of English:

\begin{tabular}{|c|c|c|}
\hline (2) $\mathrm{RP}$ & Efik & \\
\hline /s3:vei/ & [sıféé] & - survey \\
\hline /flavo/ & [fráwà] & - flower/flour \\
\hline /vi:zə/ & [físà] & - visa \\
\hline /beilif/ & [bélif] & - bailiff \\
\hline /vælv/ & [fálf] & - valve \\
\hline
\end{tabular}

The last two examples in 2 are used to demonstrate the fact that though the voiceless labio-dental sound /f/ does not occur in word final position in Efik, such an occurrence is possible with loanword adaptation. Again, all the instantiations of $/ \mathrm{v} /$ with respect to environment of occurrence are realised as $/ \mathrm{f} /$. The mapping of L1 form onto L2 form here is as a result of close phonological equivalence which also shows that devoicing is an important parameter in English loanwords adaptation in Efik.

\subsubsection{The Adaptation of Dental Consonants}

The English labial-dental fricative $/ \theta /$ and $/ \delta /$ which are not in the Efik phonological inventory are adapted as the alveolar plosives /t/ and /d/ respectively as we can see in (3):

(3) $\mathrm{RP}$

Efik

$\begin{array}{lll}/ \theta \text { aoznd/ } & {[\text { tısìn }} & \text { - thousand } \\ / \theta \text { s:msstæt/ } & \text { [témóstàt] } & \text { - thermostat } \\ / \text { weðə(r)/ } & \text { [wéedà] } & \text { - weather }\end{array}$




$$
\text { /leðə(r)/ [léedà] - leather }
$$

The voiceless dental fricative is substituted with the voiceless alveolar plosive and the voiced counterpart with the corresponding voiced plosive. This is another case of sound substitution in terms of closeness of features to fit into the canonical Efik nativised phonological system.

\subsubsection{The Adaptation of Alveolar Consonants}

The absence of the voiced alveolar fricative / $\mathbf{z}$ / has paved way for its adoption either as a voiceless alveolar plosive / $\mathrm{t} /$ mainly in the initial position or as its voiceless counterpart /s/ in most other contexts. The adopted sounds share the same phonetic environment in terms of place and manner of articulation. The sound /s/ can occur in all positions as a substitution for $/ z /$ in the indigenous phonological system.

$\begin{array}{lll}\text { (4) RP } & \text { Efik } & \\ \text { /zịk/ } & {[\text { tíán }} & \text { - zinc } \\ \text { /zu:/ } & {[\text { sú: }]} & \text { - zoo } \\ \text { /d } \_ \text {zn/ } & {[\text { disìn }]} & \text { - dozen } \\ \text { /fez kæp/ } & {[\text { fés káp] }} & \text { - fez cap }\end{array}$

The adaptation of the sound $/ z /$ as $/ t /$ in the first example in 4 is more as a result of indigenous innovation not necessarily as a result of any phonological approximation of the sounds involved. A similar case is seen in the adaptation of $/ \mathrm{k} /$ in $/ \mathrm{kændl} / \mathrm{as} / \mathrm{t} /$ in the Efik equivalent form [tiande] "candle". This kind of counter example has been described by Paradis \& Lacharite (1997) as ill-formed which cannot be justify on the basis of a rule of strong adaptation tendency, though it has been minimally repaired. Apart from this segmental malformation, every instantiation of $/ \mathrm{z} /$ is manifested as $/ \mathrm{s} /$ in Efik. This is another example of devoicing as an adaptation strategy.

The trill alveolar sound / $\mathrm{r} /$ which has allophones in English can only function in word-medial position in Efik. In the initial position, it is adapted as a voiced alveolar plosive as in the initial environment we can see in (5):

$\begin{array}{lll}\text { (5) RP } & \text { Efik } & \\ \text { /refəri:/ } & \text { [défírí] } & \text { - referee } \\ \text { /refərendəm/ } & \text { [difirendum] } & \text { - referendum }\end{array}$

English words that begin with this sound are changed to the voiced alveolar plosive /d/, which share a similar phonological environment. It however, retains complete correspondence in the medial position. English words that end in this sound are completely dispensed with in Efik. The lateral approximant alveolar sound /1/ initially was not a consonant in Efik but due to the increasing effect of borrowing and language change, the sound is gaining some phonetic status in the language. English words involving it were adapted either as a voiced alveolar plosive /d/, or a trill / $\mathrm{r}$, and when it involves consonant clustering, it is either neutralized as a trill or deleted as it were as we can see in (6):

(6) RP

Efik

$\begin{array}{lll}/ \text { letə(r)/ } & \text { [détà] } & \text { - letter } \\ \text { /bəlu:n/ } & \text { [bórómbóró] } & \text { - ballon } \\ \text { /flavə/ } & \text { [fráwá] } & \text { - flower/flour } \\ \text { /singlət/ } & \text { [síñkìni] } & \text { - singlet }\end{array}$

As a matter of rule, the lateral sound is adapted as an alveolar consonant in word-initial positions given that the two sounds share the features of voiceness and alveolarity in common. /1/ is adapted phonologically as a trill intervocalically. However, in most recent borrowing, this sound has been attested in all word environments.

(7) RP

\begin{tabular}{|c|c|c|}
\hline /lə:jə(r)/ & [lıyà] & - lawyer \\
\hline /lu:və(r) & [lófàs] & - louvers \\
\hline /pailət/ & [kpáilot] & - pilot \\
\hline /dplə(r)/ & [dilà] & - dollar \\
\hline /wol/ & [wúl] & - wool \\
\hline
\end{tabular}




$$
\text { /tu:l/ [túl] - tool }
$$

On the strength of its occurrence in all word positions, it becomes compelling to analyse its as a phonetic consonant in Efik.

\subsubsection{The Adaptation of Palatal Consonants}

Apart from the palatal approximant $/ \mathrm{j} /$, none of the other palatal consonants is attested in Efik. A number of strategies has been adopted in the adaptation of these sounds in Efik. The voiceless palato- alveolar fricative $/ \mathrm{J} /$ is realised as the voiceless alveolar fricative /s/ in the initial and medial environments. The features of frication and voicelessness tend to motivate this sound change as we can see below:

\begin{tabular}{|c|c|c|}
\hline$(9)$ & Efik & \\
\hline / Jugə(r)/ & [súkà] & - sugar \\
\hline /məSi:n/ & [màsín] & - machine \\
\hline /hæyket Si:f/ & [ánkìsì] & - handkerchief \\
\hline /mezə(r)/ & [méisวo] & - measure \\
\hline
\end{tabular}

The voiced post-alveolar fricative is equally adapted as a voiceless alveolar stop in word-medial positions as the last example in 9 demonstrates. Notice the effect of lengthening in filling a perceptual gap in the L2 phonology in the last example in 9. This evidence demonstrates that lengthening is a factor in the adaptation of English loanwords in the Efik. Length is contrastive in Efik as in bok "cook" and book "rear" as such some English words are lengthened as an adaptation strategy in Efik, though this may only affect vowels:

(10)

$\begin{array}{lll}\text { RP } & \text { Efik } & \\ / \text { ba:(r)/ } & \text { [báá] } & - \text { bar } \\ / \text { kpfi/ } & \text { [k1fíi] } & \text { - coffee } \\ \text { /s3:vei/ } & \text { [sóféè] } & \text { - survey } \\ \text { /ba:bə(r)/ } & \text { [báabà] } & \text { - barber }\end{array}$

The phonological environment in which a vowel can be lengthened is predictable, usually with a CVV structure where a consistent tone assignment is based on the segmental composition of the input. We can ascribe this phenomenon to calquing, which reflects the language - specific facts of the recipient language phonology (Kang 2010).

In the case of the palatal affricate sounds, $/ \mathrm{t} f /$ occurs as a voiceless alveolar plosive $/ \mathrm{t} /$ while the voiced counterpart $/ \mathrm{d} 3 /$ is realised in two ways; either as a palatal approximant $/ \mathrm{j} /$ or as a voiced alveolar plosive $/ \mathrm{d} /$ :

$\begin{array}{lll}\text { RP } & \text { Efik } & \\ / \mathrm{ti}: \mathrm{t} \int \partial(\mathrm{r}) / & {[\text { títìa] }} & \text { - teacher } \\ / \mathrm{d} 3 e l ə s i / & \text { [jéləsí] } & \text { - jealousy } \\ / \text { mæd3ik/ } & \text { [májik] } & \text { - magic } \\ / \text { ed3ukeit/ } & \text { [édúkéit] } & \text { - educate }\end{array}$

These sounds are adapted by a process of consonant substitution taking into account closeness of features in an attempt to fill notable consonantal gaps that will satisfy the requirements of the L2 phonology.

\subsubsection{The Adaptation of Velar Consonants}

The voiced velar plosive /g/ occurs in English words in all environments but is not present in the Efik phonological system. It is therefore, substituted with the voiceless counterpart $/ \mathrm{k} /$ which in attested in Efik loanwords in both initial and medial environments. In the initial position, it is noted that the adapted sound is preceded by an epenthentic vowel:

$\begin{array}{lll}\text { RP } & \text { Efik } & \\ / \text { gla:s/ } & \text { [ákrâsí] } & \text { - glass } \\ \text { /digri:/ } & \text { [dikiríi } & \text { - degree } \\ / \text { / vgə(r)/ } & \text { [súkà] } & \text { - sugar }\end{array}$

What could be the motivation for epenthesis? As a matter of rule, a majority of Efik indigenous nouns begins with vowels, thus nouns that begin with consonants are mainly loanwords. Therefore the initial vowel sound is 
introduced for ease of pronunciation and to assimilate the sound in the direction of Efik. Kedenga and Mabugu (2009) have pointed out that in Shona, a South African language, epenthetic vowels are used to break up consonant clusters to fit the traditional syllable structure of the language which only permit a single consonant in an onset. Ojukwu and Mensah (2003) have also observed a similar trend in Yoruba. Further evidence of breaking up of consonant clustering in Efik loan nouns can be seen in 13:

$\begin{array}{lll}\text { RP } & \text { Efik } & \\ / \mathrm{t} \wedge \text { mblə(r)/ } & \text { [tómbìt }] & \text { - tumbler } \\ / \text { səuldzə(r)/ } & \text { [sóyà] } & \text { - soldier } \\ / \text { singlət/ } & \text { [síñkìni] } & \text { - singlet }\end{array}$

The introduction of vowels in the adaptation of these words is to break the /-mbl-/, /-ld3-/ and / ggl/ clustering. A rule breaking up consonant clustering, which is a natural process is many worlds' languages can be stated thus:

(14) $\mathrm{O} \rightarrow[\mathrm{V}] / \mathrm{C}-\mathrm{C}(\mathrm{C})$

Where a vowel sound is inserted in the environment of two (or more) consonants occurring together. The environment of occurrence of either sound is not predictable as there is no established system. The choice largely depends on perception and articulation.

\subsubsection{Adaptation of the Glottal Consonant}

The glottal fricative / $\mathrm{h} /$ is always silent in Efik during adaptation in the initial and medial positions in English loanwords.

(15) RP

$\begin{array}{lll}\text { /helikpptə(r) } & \text { [élíkóptà] } & \text { - helicopter } \\ \text { /hæyə(r) } & \text { [ánkà] } & \text { - hanger } \\ \text { /hæmə(r) } & \text { [ámà] } & \text { - hammer } \\ \text { /in-haus/ } & \text { [in-aus] } & \text { - in-house }\end{array}$

This evident shows that segment deletion is a strategy for the adaptation of English consonants in Efik. The glottalized fricative sound $/ \mathrm{h} /$ is phonotactically constrained to words only in the medial position in Efik:

$\begin{array}{ll}\text { [étíhí] } & \text { - okra } \\ \text { [tíhá] } & \text { - kick } \\ \text { [múho] } & \text { - be short }\end{array}$

It is interesting to note that the phonemic status of $/ \mathrm{h} /$ in Efik has generated controversial debates in the literature among scholars. While some tend to analyse it as an allophone of $/ \mathrm{k} /$ given its inability to pass the minimal pair test or occur in complementary distribution (Ward, 1933), others argue that it is a glide because of its perceptual feature of high vowel quality (Essien, 1971). In this study, we have only considered it as a phonetic sound in line with Ward's (1933) position.

\subsection{The Pedagogical Implications}

Based on the contrastive analysis approach which we adopted in this study, we are able to predict that sounds which are attested in both English and Efik require no adaptation in terms of phonological correspondence and equivalence. This category of sounds does not pose serious learning tasks or difficulties to the Efik learner of English. This is the idea of positive transfer, where the knowledge of L1 sounds facilitates the learning of L2 sounds. English sounds which are not attested in the Efik phonological inventory on the other hand have been identified as the potential areas of difficulty where errors will take place in the performance of the Efik learner of English. Learning responses interfere with one another and leads to negative transfer or interference. This is important given Lado (1957) hypothesis that learners tend to transfer L1 sounds productively into L2 when speaking L2 and receptively when attempting to grasp and understand L2

The principle of hierarchy of difficulty should also be adopted in the teaching of English sounds to Efik learners, where the most difficult sounds be placed at the top (prioritized learning) and the least difficult at the bottom. Based on the categories in the hierarchy of difficulty (Stockwell et al., 1965), we wish to propose the following degrees of difficulty for Efik-English phonological systems contrast. First, difficulty is greatest with split, where a particular sound in Efik becomes two sounds in English, for example, Efik has /f/ and /s/ while English correspondingly have /f, $\mathrm{v} /$ and /s, $\mathrm{z} /$. This has brought about negative transfer of L1 elements to account for the 
absent features in L2. This will require the learner to make new distinctions. It is also observed that difficulty is least with complete correspondence, where no difference or contrast is present. Where a sound is in Efik and not attested in English (underdifferentiation), example, the palatal nasal $/ \mathrm{n} /$, the Efik learner should be able to avoid such a sound in his/her performance in English. Where there is a set of sounds in English that is entirely new or not similar in Efik (over differentiation), example, the English post-alveolar and dental sounds $/ \int, 3, \mathrm{t} \int \mathrm{d} 3, \theta, \mathrm{d} /$, the Efik learner should be encouraged to learn such sounds rigorously.

In order to improve the communicative efficiency of the Efik learner in written and spoken English, the teacher needs to place much emphasis on the most difficult English sounds which are not attested in Efik. The teacher should also be able to point out the conspicuous differences and explain the errors arising from the learner's output. Information should be provided on why errors occur and their pedagogical significance noted. The teaching of L2 sounds should not be done in isolation since contrastive analysis is an integrative approach towards learning. Non-segmental features like stress, intonation, and syllable structure should also form part of the overall teaching module. This can help to provide insights on how language works. The overall result will help the teacher to bring performance to standard production and enable the learner to improve basic communication in English, facilitate intelligibility and boost self-esteem.

\section{Conclusion}

This paper examines the processes of English consonant adaptation in Efik from the standpoint of contrastive analysis. We examined the motivations for borrowing within the Efik socio-cultural landscape as well as their educational and communicative consequences especially in improving the linguistic resourcefulness of the Efik vocabulary which has been expanded to meet modern challenges. We compared and contrasted the consonant systems of Efik and English taking into cognizance their corresponding non-segmental or prosodic features whose effects also contribute to the understanding of meaning. We analyzed the adaptation of English consonants by Efik learners of English from the phonological approximation view of loanword adaptation and found out that the adaptation strategies involve processes such as consonant voicing, devoicing, epenthesis, substitution and deletion of sounds. Some of the changes are however as a result of indigenous innovations and prosodic patterns not necessarily as segmental motivations. The paper considers the pedagogical implications of the study taking into account the principle of hierarchy of difficulty which grades learning tasks based on a top-down approach which identifies greater forms of difficulties and analyses them further down to the least ones. The paper makes adequate recommendations to help the teacher fill some pedagogical gaps in the teaching of English sounds to the Efik learner of English.

\section{Acknowledgements}

This research was funded by the Leventis Foundation, Centre of African Studies, School of Oriental and African Studies (SOAS), University of London, UK, to whom we express our deep gratitude. We thank all the respondents who participated in the study and two anonymous reviewers of this article. Any errors that remain are ours.

\section{References}

Ahukanna, J. (1990). Bilingualism and code-mixing in language use in Nigeria: The case of Igbo-English bilinguals. In E. N. Emenanjo (Ed.), Multilingualism, Minority Languages and Language Policy in Nigeria (pp. 175-185). Agbor: Central Books Limited.

Anderson, J. (2001). A major restructuring in the English consonant system: The de-linearization of [h] and the de-consonantalization of [w] and [j]. English Language and Linguistics, 5(2), 199-212.

Borowsky, T. (1989). Structure preservation and the syllable coda in English. Natural Languages and Linguistic Theory, 7, 145-166.

Celik, M. (2001). Teaching English intonation to EFL/ESL students. The Internet TESL Journal, 7(12). Retrieved from http://www.iteslj.org

Chang, C. (2008). Phonetics vs. phonology in loanword adaptation: Revisiting the role of bilinguals. University of Berkeley Phonology Lab Annual Report, 43-54.

Cook, T. (1969). The pronunciation of Efik for speakers of English. Bloomingfield: Indiana University Press.

Cook, T. (1986). An integrated phonology of Efik. Foris: Dordrecht.

Delahunty, G., \& Gavey, J. (2003). English word stress patterns. Retrieved from http://www.lamar.colostate.edu

Essien, U. (1970). The vowel system of Efik. Journal of West African Languages, 2, 103-112. 
Fisiak, J. (1981). Contrastive linguistics and the language teacher. New York: Pergamon.

Greenberg, J. (1963). Languages of Africa. Mouton: The Hague.

Hadlich, R. (1965). Lexical contrastive analysis. Modern Languages Journal, 49, 426-429.

Hoffman, L. (1991). An introduction to bilingualism. New York: Longman.

Jones, D. (2003). English pronouncing dictionary. Cambridge: Cambridge University Press.

Kang, Y. (2010). The emergence of phonological adaptation from phonetic adaptation: English loanwords in Korean. Phonology, 27(2), 225-253.

Kedenge, M., \& Mabugu, P. (2009). The phonological characteristics of Shona loanwords from English. Nawa: Journal of language and Communication, 3(1), 101-116.

Kenstowicz, M., \& Suchato, A. (2006). Issues in loanword adaptation: A case study from Thai. Lingua, 116, 921-949.

Lado, R. (1957). Linguistics across cultures: Applied linguistics for language teachers. Ann Arbor: University of Michigan Press.

McMahon, A. (2002). Introduction to English phonology. Edinburgh University Press.

Mensah, E. (2010). The morphosyntax of code-mixing: The Efik-English perspective. Concentric: Studies in Linguistics, 36(2), 235-256.

Mensah, E., \& Ojukwu, O. (2003). A contrastive analysis of English and Efik central vowels: The pedagogical implications. In O-M. Ndimele (Ed.), Languages and linguistics in Nigeria: A festschrift for Kay Williamson (pp. 235-241). Aba: NINLAN Press.

Munro, M., \& Derwing, T. (1995). Foreign accent, comprehensibility and intelligibility in the speech of second language learners. Language Learning, 45(1), 73-97.

Nair, K. (1972). Politics and society in south-eastern Nigeria (1814-1906): A study of power, diplomacy and commerce in Old Calabar. London: Frank Cass.

Nelson, C. (1995). Intelligibility and world Englishes in the classroom. World Englishes, 14, 273-279.

Ojukwu, O., \& Mensah, E. (2006). Stricture relativity on Yoruba and Igbo implosives. LWATI, 5(2), 46-56.

Paradis, C., \& Lacharite, D. (1997). Preservation and minimality in loanword adaptation. Journal of Linguistics, $33,379-430$.

Robins, R. (1989). General Linguistics. London: Longman.

Rowan, K. (2013). The phonological manipulation of Efik in the Abakua ritual lnguage. MS School of oriental and African Studies (SOAS), University of London.

Rustipa, K. (2011). Contrastive analysis, error analysis, interlanguage and the implication to language teaching teaching. Ragam Jurnal Pengembangan Humaniora, 11(1), 16-22. Retrieved from http://www.polines.ac.id/ragam/index-files/jurnal/paper

Spencer, A. (1991). Morphological theories. Oxford: Basil Blackwell.

Stockwell, R., Bowen, J., \& Martin, J. (1965). The grammatical structure of Spanish and English. Chicago: University of Chicago Press.

Thomason, S., \& Kaufman, T. (1988). Language contact, Creolization and Genetic Linguistics. Berkeley: University of California Press.

Ward, I. (1933). The phonetic and tonal structure of Efik. Cambridge: W. Hefers and Sons.

Wardhaugh, R. (1970). The contrastive analysis hypothesis. TESOL Quarterly, 4, 124-130.

\section{Copyrights}

Copyright for this article is retained by the author(s), with first publication rights granted to the journal.

This is an open-access article distributed under the terms and conditions of the Creative Commons Attribution license (http://creativecommons.org/licenses/by/3.0/). 